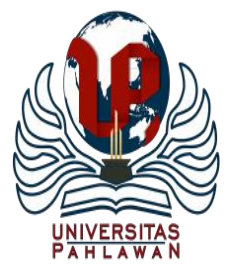

Edukatif : Jurnal Ilmu Pendidikan Volume 3 Nomor 5 Tahun 2021 Halm 1935 - 1941

EDUKATIF: JURNAL ILMU PENDIDIKAN

Research \& Learning in Education

https:/ledukatif.org/index.php/edukatif/index

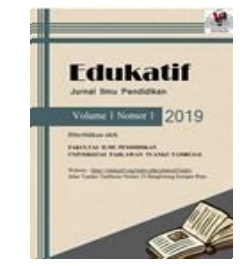

\title{
Peningkatan Hasil Belajar Matematika Melalui Model Pembelajaran Blended Learning Berbasis Blog Pada Peserta Didik di Sekolah Dasar
}

\author{
Erna Nopitasari $^{1 凶}$, Fitri Puji Rahmawati ${ }^{2}$, Wahyu Ratnawati ${ }^{3}$ \\ Universitas Muhammadiyah Surakarta, Indonesia ${ }^{1,2,3}$ \\ E-mail : ernanopitasari19@gmail.com ${ }^{1}$
}

\begin{abstract}
Abstrak
Penelitian ini merupakan penelitian tindakan kelas yang berdasarkan pada permasalahan yang ada di SDN Nglorog 1 Sragen yaitu rendahnya hasil belajar peserta didik di kelas 3 pada pembelajaran matematika di masa Covid 19 sekarang ini. Tujuan penelitian ini adalah untuk meningkatkan hasil belajar matematika melalui model pembelajaran blended learning berbasis blog. Penelitian ini dilaksanakan dengan 2 siklus 4 kali pertemuan dalam pembelajaran. Teknik pengumpulan data pada penelitian ini menggunakan metode observasi, metode tes, dokumentasi, dan catatan lapangan. Data yang dikumpulkan dalam penelitian ini meliputi data informasi tentang keadaan peserta didik dilihat dari aspek kualitatif dan kuantitatif. Aspek kualitatif adalah hasil pengamatan, hasil wawancara, catatan lapangan yang disusun oleh peneliti selama di lokasi penelitian. Data yang didapatkan di lapangan kemudian diolah dan diuji keabsahan datanya. Kemudian, di susun menjadi hasil laporan penelitian. Aspek kuantitatif yang dimaksud adalah hasil penilaian hasil belajar peserta didik. Penilaian hasil belajar diperoleh dari tes aspek pengetahuan berupa daftar nilai selama pembelajaran pada akhir siklus I dan siklus II. Uji keabsahan data menggunakan trianggulasi sumber, teknik dan waktu.
\end{abstract}

Kata Kunci: Penelitian Tindakan Kelas, Blended Learning, Hasil belajar.

\begin{abstract}
This research is a classroom action research based on the problems that exist at SDN Nglorog 1 Sragen, namely the low learning outcomes of students in grade 3 in learning mathematics in the current Covid 19 era. The purpose of this study is to improve mathematics learning outcomes through a blog-based blended learning model. This research was carried out with 2 cycles of 4 meetings in learning. Data collection techniques in this study used the method of observation, test method, documentation, and field notes. The data collected in this study includes information data about the condition of students viewed from qualitative and quantitative aspects. Qualitative aspects are the results of observations, interviews, field notes compiled by researchers while at the research location. The data obtained in the field are then processed and tested for the validity of the data. Then, compiled into the results of research reports. The quantitative aspect in question is the result of the assessment of student learning outcomes. Assessment of learning outcomes is obtained from the knowledge aspect test in the form of a list of values during learning at the end of cycle I and cycle II. Test the validity of the data using triangulation of sources, techniques and time.
\end{abstract}

Keywords: Classroom Action Research, Blended Learning, Learning Outcomes

Copyright (c) 2021 Erna Nopitasari, Fitri Puji Rahmawati, Wahyu Ratnawati

$\triangle$ Corresponding author

Email : ernanopitasari19@gmail.com

DOI : https://doi.org/10.31004/edukatif.v3i5.699

ISSN 2656-8063 (Media Cetak)

ISSN 2656-8071 (Media Online)

Edukatif : Jurnal Ilmu Pendidikan Vol 3 No 5 Tahun 2021 p-ISSN 2656-8063 e-ISSN 2656-8071 
1936 Peningkatan Hasil Belajar Matematika Melalui Model Pembelajaran Blended Learning Berbasis Blog Pada Peserta Didik di Sekolah Dasar - Erna Nopitasari , Fitri Puji Rahmawati, Wahyu Ratnawati

DOI: https://doi.org/10.31004/edukatif.v3i5.699

\section{PENDAHULUAN}

Pendidikan merupakan sebuah petunjuk bagi setiap insan manusia untuk tumbuh menjadi pribadi yang diinginkannya baik untuk dirinya maupun untuk lingkungan sekitarnya. Oleh karena itu, setiap manusia perlu menguasai keterampilan ilmu pengetahuan dan teknologi agar dapat sejalan dengan perkembangan jaman. Hasil perkembangan keilmuan di Indonesia menurut hasil riset PISA (Programme for International Strudents Assesment) menyatakan bahwa mayoritas di Indonesia para peserta didik usia 15 tahun belum memiliki kemampuan literasi dasar yang kuat. Untuk itu, pemerintah indonesia mengembangkan peningkatan pendidikan melalui implementasi abad 21 kurikulum 2013 yang dirumuskan dengan 4C, yatu berpikir kritis dan pemecahan masalah (Critical Thinking and Problem Solving Skill), kecakapan berkomunikasi (Communication Skills), kreativitas dan inovasi (Creativity and Innovation), dan kolaborasi (Collaboration). Kecakapan 4C tersebut merupakan serangkaian kecakapan yang diperlukan pada Abad 21 sekarang ini. Selain kecakapan 4C, peserta didik juga memerlukan keterampilan berpikir tingkat tinggi atau disebut Higher Order Thinking Skills (HOTS) untuk mempersiapkan peserta didik dalam menghadapi tantangan di masa yang akan datang (Kemendikbud, 2017).

Pada sekarang ini, pelaksanaan pembelajaran dilaksanakan melalui daring di mana peserta didik belajar dari rumah, sebagaimana yang tertuang dalam Surat Edaran Kemendikbud Nomor 4 Tahun 2020. Hal ini disebabkan karena adanya virus Covid-19 yang penularannya sangat cepat, sehingga menjadikan adanya pembatasan sosial. Pelaksanaan pembelajaran secara daring membuat guru yang awalnya memberikan pembelajaran secara konvensional di dalam satu ruang dan satu waktu menjadi kewalahan. Guru perlu dilatih dalam menerapkan pembelajaran yang kreatif dan inovatif dengan memanfaatkan perkembangan ilmu pengetahuan dan teknologi yang berkembang sekarang ini. Dengan adanya guru yang pandai menerapkan model pembelajaran yang kreatif dan inovatif diharapkan memberikan hasil belajar peserta didik menjadi meningkat karena guru pandai dalam memanajemen kelasnya.

Berdasarkan hasil observasi dan wawancara yang telah peneliti lakukan terhadap guru dan peserta didik di SDN Nglorog 1 Sragen, maka peneliti mendapatkan permasalahan yaitu pada pembelajaran daring peserta didik tidak aktif untuk membaca buku modul pembelajaran, sehingga meskipun soal ada di materi buku namun peserta didik masih tidak bisa mengerjakan atau nilainya tidak tuntas. Peserta didik kurang termotivasi untuk membaca materi melalui buku dan lebih aktif untuk mencari hal yang baru menggunakan mesin pencarian di internet daripada membuka buku pelajarannya. Hal ini tentunya membuat peserta didik tidak memahami materi pembelajarannya dan membuat hasil belajar peserta didik menjadi jelek. Pembelajaran matematika berarti ilmu pengetahuan yang didapat dengan berpikir. Matematika lebih menekankan kepada kegiatan dalam dunia penalaran bukan menekankan pada hasil eksperimen atau observasi. Russeffendi dalam (Siagian, 2019). Pembelajaran matematika di sekolah diarahkan kepada pencapaian standar kompetensi dasar oleh peserta didik. Kegiatan pembelajaran matematika tidak hanya berorientasi oleh peserta didik namun diposisikan sebagai alat dan sarana peserta didik untuk mencapai kompetensi. Oleh karena itu, ruang lingkup mata pelajaran matematika disesuaikan dengan kompetensi yang harus dicapai peserta didik. Ruang lingkup untuk pembelajaran matematika sekolah dasar (SD/MI) sebagai berikut: 1) Bilangan, 2) Geometri, 3) Pengolah data (Nasarudin, 2013)

Hasil belajar ialah kemampuan yang dimiliki siswa setelah ia menerima pengalaman belajarnya (Sudjana, 2009). Hasil belajar yaitu segala sesuatu yang dapat dicapai dan hasilnya maksimum dari usaha belajar yang diperoleh dengan teliti dalam belajar (Nasution, 2008). (Hamdani) menyatakan bahwa hasil adalah hasil dari suatu kegiatan yang telah dikerjakan baik secara individual maupun kelompok. Dapat disimpulkan bahwa hasil belajar adalah kemampuan yang dicapai dan hasilnya maksimum sesuai dengan usaha belajar yang dikerjakannya baik secara individu maupun secara kelompok. Beberapa fungsi penilaian hasil belajar menurut (Sudjana) antara lain : 1) alat untuk mengetahui tercapai tidaknya tujuan pembelajaran; 2) umpan balik bagi perbaikan proses belajar mengajar; 3) dasar dalam menyusun laporan kemajuan belajar siswa kepada orang tuanya.

Pada pembelajaran saat ini, kita tahu bahwa peserta didik malas untuk membaca buku modul pembelajaran. Peserta didik lebih senang belajar menggunakan handphone ataupun laptopnya. Di mana, peserta didik diberikan keleluasaan oleh orangtua atau wali peserta didik bermain handphone adalah untuk belajar secara daring. Namun, faktanya setelah mengecek tugas dari guru, peserta didik berkelanjutan mencari jawabannya menggunakan google. Sehingga, kemampuan membaca peserta didik menjadi rendah dan hasil 
1937 Peningkatan Hasil Belajar Matematika Melalui Model Pembelajaran Blended Learning Berbasis Blog Pada Peserta Didik di Sekolah Dasar - Erna Nopitasari , Fitri Puji Rahmawati, Wahyu Ratnawati

DOI: https://doi.org/10.31004/edukatif.v3i5.699

belajar peserta didik pun rendah. Untuk itu guru perlu model pembelajaran yang kreatif dan inovatif, salah satunya adalah menggunakan model Blended Learning berbasis blog. Di mana dengan model pembelajaran tersebut peserta didik bisa belajar mandiri dengan materi pembelajaran yang diberikan oleh guru. Materi pembelajaran tersebut merupakan hasil guru dalam meringkas materi dengan disesuaikan dengan kondisi sekolahnya dan diunggah di blog pribadi milik guru.

Pada penelitian yang berjudul "Penerapan Model Blended Learning untuk Meningkatkan Hasil Belajar Matematika di SDN Pisangan 01" yang ditulis oleh Adiyati Fathu Roshonah menyatakan bahwa penerapan model pembelajaran Blended Learning dapat meningkatkan hasil belajar peserta didik pada mata pelajaran Matematika materi FPB dan KPK kelas IVA di SDN Pisangan 01. Pada penelitian tersebut, dilaksanakan secara blended learning dengan guru membagikan link materi pembelajaran dan peserta didik mempelajarinya. Di kemudian hari, peserta didik melakukan pembelajaran di sekolah dengan dijelaskan materi secara sekilas dan bertanya jawab mengenai materi yang peserta didik sudah baca. Berbeda dengan pembelajaran sekarang yang semuanya dilaksanakan secara online. Untuk itu peneliti akan melakukan penelitian terhadap kelas 3 dengan menerapkan masalah pada peningkatan hasil belajar matematika melalui model pembelajaran blended learning berbasis blog pada peserta didik kelas 3 semester 2 sekolah dasar.

\section{METODE PENELITIAN}

Penelitian ini menggunakan penelitian tindakan kelas yang dilaksanakan di SDN Nglorog 1 Sragen dengan subjek penelitian adalah peserta didik kelas 3 dengan jumlah 16 peserta didik. Objek pada penelitian ini adalah hasil belajar peserta didik kelas 3 dengan penerapan model pembelajaran blended learning berbasis blog. Hasil belajar yang dimaksud adalah ketuntasan peserta didik dalam pembelajaran yang telah diterapkan yang meliputi aspek pengetahuan, sikap dan keterampilan. Penelitian tindakan kelas ini menggunakan 2 siklus dengan 4 kali pertemuan dalam pembelajaran. Dilaksanakan pada bulan November 2020 sampai dengan bulan Juni 2021. Teknik pengumpulan data yang dilakukan pada penelitian ini adalah metode observasi, metode tes, dokumentasi, dan catatan lapangan. Data yang dikumpulkan dalam penelitian ini meliputi data informasi tentang keadaan peserta didik dilihat dari aspek kualitatif dan kuantitatif. Aspek kualitatif adalah hasil pengamatan, hasil wawancara, catatan lapangan yang disusun oleh peneliti selama di lokasi penelitian. Data yang didapatkan di lapangan kemudian diolah dan diuji keabsahan datanya. Kemudian, di susun menjadi hasil laporan penelitian. Aspek kuantitatif yang dimaksud adalah hasil penilaian hasil belajar peserta didik. Penilaian hasil belajar diperoleh dari tes aspek pengetahuan berupa daftar nilai selama pembelajaran pada akhir siklus I dan siklus II.

Dalam setiap penelitian diperlukan pengujian keabsahan data. Di mana uji keabsahan data menurut William Wiersma dalam (Sugiyono, 2017), menguji keabsahan data itu dengan teknik triangulasi. Triangulasi merupakan sebuah cara pengecekan data dari berbagai sumber. Menurut (Ratna, 2010), triangulasi merupakan usaha untuk memahami suatu data penelitian dengan berbagai sumber, subjek, peneliti, cara (teori, metode, teknik), dan waktu. Sehingga, dapat disimpulkan bahwa triangulasi adalah cara untuk mengecek data dengan memahami data melalui berbagai sumber, subjek, peneliti, cara dan waktu. Pada penelitian tindakan kelas ini, triangulasi data yang digunakan ada dua, yaitu triangulasi sumber, triangulasi teknik dan triangulasi waktu. Dalam triangulasi sumber dilakukan pengumpulan data dari berbagai sumber (guru, peserta didik) kemudian dianalisis oleh peneliti sehigga dihasilkan suatu kesimpulan dan dimintakan kesepakatan dari sumber yang bersangkutan. Data yang diperoleh peneliti terhadap sumber adalah observasi dan wawancara. Sehingga, peneliti pada saat keabsahan data triangulasi teknik menggunakan teknik kuesioner terhadap sumber. Sedangkan trianggulasi waktu adalah waktu dalam 4 kali pertemuan yang berbeda waktunya.

Indikator keberhasilan dalam penelitian tindakan kelas ini merupakan indikator menjadi tolak ukur dalam menyatakan bahwa pembelajaran yang berlangsung selama penelitian berhasil untuk meningkatkan hasil peserta didik pada pembelajaran matematika kelas 3 semester 2. Penelitian ini diakhiri setelah peserta didik mengalami peningkatan hasil belajar pada pembelajaran matematika dengan nilai ketuntasan minimal di sekolah adalah 68 . 
1938 Peningkatan Hasil Belajar Matematika Melalui Model Pembelajaran Blended Learning Berbasis Blog Pada Peserta Didik di Sekolah Dasar - Erna Nopitasari , Fitri Puji Rahmawati, Wahyu Ratnawati

DOI: https://doi.org/10.31004/edukatif.v3i5.699

\section{HASIL DAN PEMBAHASAN PENELITIAN}

Penelitian Tindakan kelas ini dilaksanakan secara daring menggunakan aplikasi pembelajaran zoom. Model pembelajaran yang diteliti adalah model pembelajaran blended learning berbasis blog pada fokus materi matematika di kelas 3 dengan 2 siklus 4 kali pertemuan dalam. Menurut Syah dalam (Syafi'i, dkk, 2018) Hasil sebuah hasil dari belajar tentunya memiliki aspek yang bisa menjadi indikator terhadap pencapaian dalam belajar. Aspek-aspek tersebut setidaknya ada tiga (3) aspek hasil belajar yang ketiganya dapat dikaji dalam berbagai literasi. Pertama adalah aspek kognitif. Aspek kognitif sebagai indikator dalam pencapaian sebuah hasil hal ini seperti yang disampaikan oleh Muhibbin Syah bahwa "untuk mengukur hasil siswa bidang kognitif ini dapat dilakukan dengan berbagai cara, baik dengan tes tulis maupun tes lisan". Kedua adalah aspek afektif. Aspek afektif ialah ranah berfikir yang meliputi watak perilaku seperti perasaan, minat, sikap, emosi, atau nilai. Menurut Harun Rasyid dan Mansur "ranah afektif menentukan keberhasilan belajar seseorang. Orang yang tidak memiliki minat pada pelajaran tertentu sulit untuk mencapai keberhasilan studi secara optimal. Seseorang yang berminat dalam suatu mata pelajaran diharapkan akan mencapai hasil pembelajaran yang optimal (Mansur, 2007). Ketiga adalah Aspek psikomotorik. Psikomotorik merupakan aspek yang berhubungan dengan olah gerak seperti yang berhubungan dengan otot-otot syaraf misalnya lari, melangkah, menggambar, berbicara, membongkar peralatan atau memasang peralatan dan lain sebagainya.

Dalam pembelajaran pra siklus yang dilakukan, hasil belajar matematika peserta didik masih sangat rendah yaitu lebih dari $80 \%$ peserta didik masih mendapatkan nilai di bawah 68, artinya bahwa ada 12 siswa yang mendapatkan nilai dibawah 70 dan hanya 4 siswa yang mendapatkan nilai diatas 68 . Hal ini disebabkan karena pada kondisi pandemi seperti ini kegiatan pembelajaran tidak dapat dilaksanakan secara tatap muka melainkan melalui daring dengan aplikasi whatsapp. Pada kegiatan pembelajaran daring belum menggunakan media pembelajaran apapun dalam kegiatan pembelajaran, hanya menggunakan modul buku guru dan buku peserta didik sebagai acuan guru dalam menjelaskan materi. Sehingga kegiatan pembelajaran bersifat pasif, hasil belajar peserta didik pun banyak yang di bawah KKM karena kurangnya pemahaman terhadap materi yang disampaikan.

Pada Siklus I, guru memberikan modifikasi dalam penelitiannya yaitu menggunakan model pembelajaran blended learning berbasis blog. Dengan tahap persiapan yang dilakukan oleh guru adalah sebagai berikut : 1) Rencana Pelaksanaan Pembelajaran (RPP), 2) Instrumen evaluasi, 3) Lembar Kerja Peserta Didik (LKPD), 4) Media Pembelajaran. Media pembelajaran menggunakan media blog. Media pembelajaran disusun dengan konsep agar peserta didik antusias dalam membaca dan aktif dalam kegiatan pembelajaran dan memenuhi indikator capaian yang telah ditentukan.5) Bahan Ajar

Pelaksanaan siklus I dilaksanakan dengan menggunakan media pembelajaran blog di mana guru mengirimkan materi melalui blog terlebih dahulu untuk dibaca peserta didik. Pertemuan I dilaksanakan pada tanggal 28 Januari 2021 dan pertemuan II dilaksanakan pada tanggal 4 Februari 2021. Waktu pelaksanaan pembelajaran adalah pukul 09.00 WIB sampai pukul 10.30 WIB. Pada pertemuan I dan II peneliti melaksanakan pembelajaran secara online blended learning melalui zoom, sebelum memulai pembelajaran peserta didik dibagikan link blog yang berisi rangkuman materi yang dibuat oleh guru secara menarik. Pada pertemuan ini, meliputi tiga tahap, yaitu kegiatan pendahuluan, kegiatan inti dan kegiatan akhir berupa refleksi dan evaluasi. Kompetensi dasar dalam pembelajaran matematika pada siklus I meliputi: 1) Menjelaskan dan menentukan lama waktu suatu kejadian berlangsung, 2) Menyelesaikan masalah yang berkaitan lama waktu suatu kejadian berlangsung.

Hasil dalam penelitian siklus 1 didapatkan dari nilai soal evaluasi yang dikerjakan. Hal ini dilakukan agar data yang diperoleh valid. bahwa hasil belajarnya meningkat dengan table presentasenya adalah sebagai berikut :

Tabel 1. Presentase Hasil Belajar Peserta Didik Siklus I

\begin{tabular}{|l|c|c|}
\hline \multirow{2}{*}{ Kriteria } & \multicolumn{2}{c|}{ Frekuensi } \\
\cline { 2 - 3 } & Pertemuan I & Pertemuan II \\
\hline Tuntas & 6 & 7 \\
\hline Belum Tuntas & 10 & 9 \\
\hline
\end{tabular}


1939 Peningkatan Hasil Belajar Matematika Melalui Model Pembelajaran Blended Learning Berbasis Blog Pada Peserta Didik di Sekolah Dasar - Erna Nopitasari, Fitri Puji Rahmawati, Wahyu Ratnawati

DOI: https://doi.org/10.31004/edukatif.v3i5.699

Refleksi yang perlu menjadi perhatian untuk guru terhadap pelaksanaan tindakan pada siklus I ini ditemukan beberapa kelemahan selama proses pembelajaran, di antaranya sebagai berikut: 1) Guru tidak mengecek tentang kesiapan peserta didik dalam pembelajaran, melalui pertanyaan pemantik yang sesuai dengan materi yang telah guru share melalui blog. 2) Peserta didik saat pembelajaran melalui zoom kurang fokus dan sering teralihkan perhatiannya oleh lingkungan sekitarnya.

Dari temuan tersebut, terdapat tindakan yang harus ditambahkan atau diubah pada saat pembelajaran adalah sebagai berikut :1) Pertanyaan pemantik yang diberikan guru harus disiapkan dengan matang dan disesuaikan dengan kehidupan sehari-hari peserta didik berdasarkan pengalamannya, 2) Guru selalu memberikan peringatan kepada peserta didik untuk selalu fokus dengan berkata "Ayo kelas 3 fokus yuk".

Perencanaan pembelajaran pada siklus ke II sama dengan perencanaan pembelajaran di siklus I. Hanya saja, pada saat pelaksanaan pembelajaran, guru lebih memperhatikan catatan yang menjadi refleksi dalam pembelajaran siklus I. Pelaksanaan pembelajaran pada siklus II dilaksanakan dengan menggunakan media pembelajaran blog di mana guru mengirimkan link blog melalui whatsapp yang berisi file materi untuk kemudian dibaca peserta didik. Pertemuan II dilaksanakan pada tanggal 11 Februari 2021 dan pertemuan II dilaksanakan pada tanggal 18 Februari 2021. Waktu pelaksanaan pembelajaran adalah pukul 09.00 WIB sampai pukul $10.30 \mathrm{WIB}$.

Pada pertemuan I dan II peneliti melaksanakan pembelajarannya secara online dengan model blended learning melalui aplikasi zoom, sebelum memulai pembelajaran peserta didik dibagikan link blog melalui whatsapp. Link blog tersebut berisi rangkuman materi yang dibuat oleh guru secara menarik. Pada pembelajaran ini dilaksanakan dengan tiga kegiatan, yaitu kegiatan pendahuluan, kegiatan inti dan kegiatan akhir berupa refleksi dan evaluasi. Kompetensi dasar dalam pembelajaran matematika pada siklus II meliputi:1) Menjelaskan dan menentukan lama waktu suatu kejadian berlangsung., 2) Menyelesaikan masalah yang berkaitan lama waktu suatu kejadian berlangsung.

Tabel persentase pada siklus II pertemuan 1 dan ke 2 hasil belajarnya adalah sebagai berikut :

Tabel 2. Presentase Hasil Belajar Peserta Didik Siklus II

\begin{tabular}{|l|c|c|}
\hline \multirow{2}{*}{\multicolumn{1}{c|}{ Kriteria }} & \multicolumn{2}{c|}{ Frekuensi } \\
\cline { 2 - 3 } & Pertemuan I & Pertemuan II \\
\hline Tuntas & 9 & 12 \\
\hline Belum Tuntas & 6 & 4 \\
\hline
\end{tabular}

Refleksi digunakan untuk mengkaji apa yang sudah digunakan atau hasil yang telah didapatkan selama penelitian tindakan siklus II berlangsung, hasil belajar peserta didik pada siklus II sudah sesuai dengan apa yang diharapkan. Peserta didik yang mendapatkan nilai 68 ke atas sejumlah 12 siswa, jika dipersentasekan sebanyak $75 \%$ peserta didik mendapatkan hasil belajar dengan nilai lebih dari 68 . Banyak faktor yang mempengaruhi belajar terdapat beberapa jenis. Secara umum, dibagi menjadi dua golongan yaitu internal dan eksternal (Slameto, 2013), berikut ini adalah penjabarannya :

Faktor internal adalah faktor yang ada dalam diri individu yang sedang belajar. Faktor internal terbagi menjadi tiga faktor yaitu faktor jasmaniah, faktor psikologis, dan faktor kelelahan. Faktor jasmaniah dapat disebabkan oleh kesehatan dan cacat tubuh. Kesehatan seseorang berpengaruh terhadap proses belajar yang sedang dilakukannya, proses belajar seseorang akan terganggu jika kesehatan seseorang akan terganggu sehingga mengakibatkan lelah, kurang bersemangat, sakit kepala, mengantuk, kurang darah ataupun ada gangguan-gangguan fungsi alat indera serta tubuhnya. Keadaan cacat tubuh juga mempengaruhi belajar. Siswa yang mengalami cacat belajarnya juga akan terganggu, sehingga hendaknya belajar pada lembaga pendidikan khusus atau diusahakan alat bantu untuk mengurangi dampak kecacatannya. Faktor psikologis terdiri dari tujuh faktor, yaitu inteligensi, perhatian, minat, bakat, motif, kematangan, dan kesiapan. Sedangkan faktor kelelahan terbagi menjadi dua faktor yaitu kelelahan jasmani dan kelelahan rohani.

Faktor eksternal adalah faktor yang ada di luar individu. Faktor eksternal yang dapat mempengaruhi proses belajar digolongkan menjadi tiga yaitu faktor keluarga, faktor sekolah, dan faktor masyarakat. Faktor keluarga mempengaruhi proses belajar siswa melalui cara orang tua mendidik, relasi antar anggota keluarga, suasana rumah, keadaan ekonomi keluarga, pengertian orang tua, dan latar belakang kebudayaan. Sekolah merupakan tempat siswa melaksanakan proses belajar secara formal, komponen yang ada di sekolah dapat mempengaruhi proses belajar siswa. Komponen yang mempengaruhi belajar siswa adalah metode mengajar, kurikulum, relasi guru dengan siswa, relasi siswa dengan siswa, disiplin sekolah, alat pelajaran, waktu 
1940 Peningkatan Hasil Belajar Matematika Melalui Model Pembelajaran Blended Learning Berbasis Blog Pada Peserta Didik di Sekolah Dasar - Erna Nopitasari , Fitri Puji Rahmawati, Wahyu Ratnawati

DOI: https://doi.org/10.31004/edukatif.v3i5.699

sekolah, standar pelajaran, keadaan gedung, metode belajar, dan tugas rumah, Sedangkan faktor masyarakat yang dapat mempengaruhi belajar siswa adalah kegiatan siswa dalam masyarakat, media massa, teman bergaul, dan bentuk kehidupan masyarakat.

Faktor internal dari peserta didik pada pembelajaran di masa pandemic ini adalah peserta didik yang kurang bersemangat, mengantuk. Terutama pembelajaran yang dilaksanakan di bulan puasa Ramadhan. Sedangkan faktor eksternal adalah peserta didik yang handphonenya dibawa oleh orangtuanya bekerja. Namun semuanya dapat diatasi oleh guru kelas. Guru di setiap pembelajaran selalu membagikan link blog di sore hari sebelum pembelajaran, peserta didik bisa membaca materi pembelajaran kapanpun dan dimanapun belajar dilaksanakan dengan tanpa mengunduh file materi pembelajaran.

Peneliti menghadapi beberapa keterbatasan yang dapat dipengaruhi dari kondisi penelitian yang dilakukan. Adapun keterbatasan tersebut antara lain: 1) Penelitian ini hanya dilaksanakan dengan dua siklus, jika dilaksanakan dengan lebih banyak siklus masih terdapat kemungkinan akan menjadi lebih baik, 2) Jumlah peserta didik dalam penelitian ini hanya 16. Terdapat kemungkinan jika diterapkan pada jumlah peserta didik yang berbeda akan mendapatkan hasil yang berbeda pula.

Namun demikian, hasil penelitian ini setidaknya dapat digunakan sebagai acuan bagi kepala sekolah, guru dan peserta didik bahwa motivasi dan hasil belajar sangatlah penting dan dapat ditingkatkan melalui pembelajaran dengan menggunakan model blended learning menggunakan media blog dapat meningkatkan motivasi dan hasil belajar peserta didik.

\section{KESIMPULAN}

Berdasarkan hasil penelitian dan pembahasan yang telah dilakukan ini dapat disimpulkan bahwa pada penelitian ini menunjukkan peningkatan dalam hasil belajar peserta didik yang awalnya kurang dari $50 \%$ peserta didik yang mendapatkan hasil belajar tinggi, menjadi lebih dari $75 \%$ peserta didik dari 16 peserta didik hasil belajarnya tinggi. Hasil belajar dari peserta didik dalam pembelajaran dengan menggunakan model blended learning menggunakan media blog dipengaruhi oleh beberapa faktor internal maupun eksternal peserta didik. Namun, semuanya dapat teratasi oleh guru kelas. Di mana guru di setiap pembelajaran selalu membagikan link blog di sore hari sebelum pembelajaran, peserta didik bisa membaca materi pembelajaran kapanpun dan dimanapun belajar dilaksanakan dengan tanpa mengunduh file materi pembelajaran.

\section{DAFTAR PUSTAKA}

Kementerian Pendidikan dan Kebudayaan. (2017). Panduan Implementasi Kecakapan Abad 21 Kurikulum 2013 di Sekolah Menengah Atas.

Nasarudin. 2019. Karakteristik dan Ruang Lingkup Pembelajaran di Sekolah. Papopo: Prodi Pendidikan Matematika Jurusan Tarbiyah STAIN Papopo

Nasution, S. (2008). Berbagai Pendekatan dalam Proses Belajar \& Mengajar. Bumi Aksara.

Nurdin, Syafruddin. 2016. Guru Profesional dan Penelitian Tindakan Kelas. JURNAL EDUCATIVE : Journal of Education Studies. 1 (1). 1-12

Ratna, Nyoman Kutha. 2010. Metodologi Penelitian Kajian Budaya dan Ilmu-ilmu Sosial Humaniora Pada Umumnya. Yogyakarta: Pustaka Pelajar.

Rusman . (2013). Model-model Pembelajaran. Jakarta: PT. Rajagrafindo

Sari, Milya. (2016). Blended Learning, Model Pembelajaran Abad Ke-21 Di Perguruan Tinggi.Ta'dib, Jurnal Fakultas Pendidikan dan Pelatihan Guru, Universitas Batusangkar, 17(2), 126-136.

Slameto. (2013). Belajar dan Faktor-Faktor yang Mempengaruhinya. Rineka Cipta.

Sukmawati, dkk. (2017). Pengembangan Model Blended Learning Menggunakan Blog, Jurnal Vidya Karya, Program Studi Ilmu Komputer FKIP Universitas Lambung Mangkurat, 32 (2), 117-122.

Sudarman. 2014. Pengaruh Strategi Pembelajaran Blended Learning Terhadap Perolehan Belajar Konsep Dan Prosedur Pada Mahapeserta didik Yang Memiliki Self-Regulated Learning Berbeda. Jurnal Pendidikan dan Pembelajaran. 21 (1). 107-117.

Sudjana, N. (2009). Penilaian Hasil Proses Belajar Mengajar. Remaja Rosdakarya.

Sugiyono. (2013). Metode Penelitian Kuantitatif, Kualitatif, dan RnD. Bandung: Alfabeta. 
1941 Peningkatan Hasil Belajar Matematika Melalui Model Pembelajaran Blended Learning Berbasis Blog Pada Peserta Didik di Sekolah Dasar - Erna Nopitasari, Fitri Puji Rahmawati, Wahyu Ratnawati DOI: https://doi.org/10.31004/edukatif.v3i5.699

2016. Metode Penelitian dan Pengembangan (Research and Development/R\&D). Bandung: Alfabeta.

2017. Metode Penelitian Pendidikan (Pendekatan Kuantitatif, Kualitatif dan R\&D). Bandung: Alfabeta.

Suyadi. 2015. Panduan Penelitian Tindakan Kelas. Diva Press: Jogjakarta 